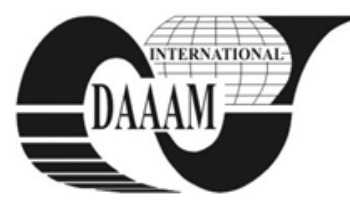

\title{
A STATISTICAL STUDY REGARDING ESTHETIC LINE CHANGES BEFORE AND AFTER ORTHODONTIC TREATMENT
}

\author{
MUNTEAN, E[lena] A[driana]; BRATU, E[lisabeta]; VALCEANU, A[nca] S[ilvia]; \\ SZUHANEK, C[amelia] A[lexandrina] \& VERNIC, C[orina]
}

\begin{abstract}
The purpose of this cephalometric investigation was to determine the changes in the soft tissue profile in a group of Romanian patients treated with fixed appliance, by evaluating the position of the esthetic line of Ricketts before and after treatment. The aim of the study was also to determine if the Angle class had any influence on the facial esthetics following orthodontic treatment. The material comprised the lateral cephalometric radiographs of 41 patients from the Department of Orthodontics of the University of Medicine and Pharmacy Victor Babes Timisoara. The patients were with ages between 12-16 years old. Cephalometric analysis was used to determine the Angle Class and position of the upper and lower lips to the esthetic line of Ricketts. Improvement of facial aesthetics by orthodontic treatment was significant for Class II division 1, and Class II division 2 patients, but not for Class I and III patients. After treatment, upper and lower lips were more retrusive for class II patients.
\end{abstract}

Key words: esthetic line, orthodontics, cephalometric analysis, angle class.

\section{INTRODUCTION}

Success in orthodontic practice is closely related to observable enhancement in the esthetic outcomes of the treatment, may therefore evaluating facial profile esthetics, both before and after treatment, is an integral part of the orthodontic treatment philosophy(Kiekens et al.,2008; Szuhanek et al., 2009; Bishara et al.,1998). Sometimes the orthodontist's will to correct the bite may even result in a decrease of facial attractiveness(Ackerman et al., 2004;Birkeland et al., 1999).

All orthodontists nowadays admit that success in orthodontic treatment is closely tied to favourable changes in facial soft tissue(Bravo L.A, 1994; Bowman et al., 2000).

\section{MATERIALS AND METHODS}

The study took place in the Department of Esthetic Dentistry, University of Medicine and Pharmacy "Victor Babes" Timisoara. The aims of the study were to determine the changes in the soft tissue profile in a group of Romanian patients by evaluating the position of the esthetic line of Ricketts before and after orthodontic treatment. The possible influence of Angle class was also studied.

For this investigation, a group of 41 patients with ages between 12-16 years old from the Department of Orthodontics of the University of Medicine and Pharmacy Victor Babes Timisoara was selected. The inclusion criteria for the patients was treatment time duration up to 3,3 years and no dental or facial trauma.

The distances between the upper and lower lips and the aesthetic line were measured on profile cephalometric radiographs.

Angle Classifications were defined as follows: Angle Class I: neutro-occlusion and neutro-relationship of the jaws; Class II division 1: disto-occlusion and disto-relationship of the jaws, with proclined upper incisors; Class II division 2: distoocclusion and disto-relationship of the jaws, with retroclined upper incisors; and Class III: mesio-occlusion and mesiorelationship of the jaws.

Neither the severity of the malocclusion nor the chosen treatment modality was important for this study, since the aim was to determine only the change in facial aesthetics after orthodontic treatment.

The soft tissue measurements used to evaluate the facial profile changes in this study were made using pre and posttreatment lateral cephalometric radiographs taken at the beginning and the end of treatment. All radiographs were taken on the same cephalostat with the patient in a standing position, with the Frankfurt plane parallel to the horizontal, the teeth in centric occlusion and lips relaxed. All radiographs were traced and measured by same investigator, using Cephx program of online measurements. Cephalograms were oriented with the facial profile to the right.

\section{RESULTS AND DISCUSSION}

The parameter evaluated before and after finishing the treatment was the relationship of the upper and lower lips to Rickett's esthetic line. The changes resulting from treatment was statistically analysed. The 12-16 age group comprised of 23 women $(56.1 \%)$ and 18 men $(43.9 \%)$, with an average age of $13.78+/-1.458(12.16)$. Among these, $51.2 \%$ had a malocclusion of Angle class II, $34.1 \%$ were in the Angle class I, while $14.6 \%$ had a molar relation of Angle class III as presented in the table 1 and graphically in the fig. 1.

\begin{tabular}{|c|c|c|}
\hline Class & Frequency & Percentage \\
\hline I & 14 & 34.1 \\
\hline II & 21 & 51.2 \\
\hline III & 6 & 14.6 \\
\hline Total & 41 & 100.0 \\
\hline
\end{tabular}

Tab. 1. The distribution of the patient lot with ages between 1216, in Angle classes.

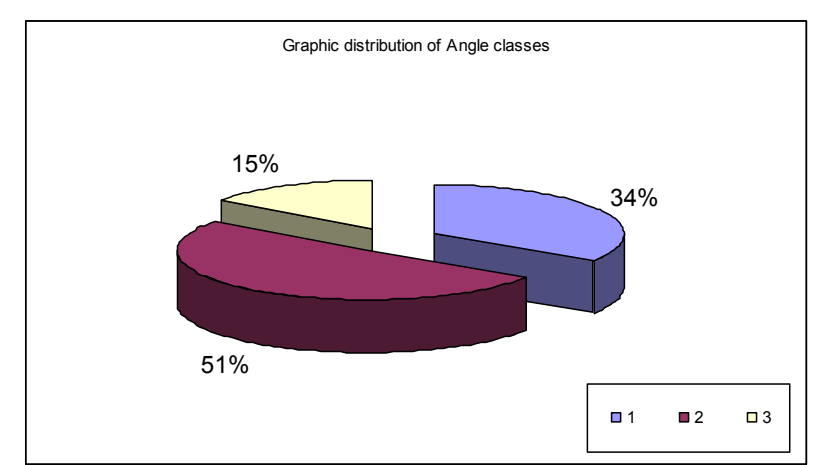

Fig. 1. Graphic distribution of the Angle classes for the group of patients 
By calculating the distance between the aesthetic line of Ricketts and the upper and lower lips for each patient, statistically significant differences were observed for Angle class II, as for the distance from the upper lip $(p=0.04825, S)$. The results are presented in table no. 2 .

\begin{tabular}{|c|c|c|c|}
\hline $\begin{array}{c}\text { Initial distance } \\
\text { aesthetic line }- \\
\text { upper lip }\end{array}$ & $\begin{array}{c}\text { Final distance } \\
\text { aesthetic line } \\
- \text { upper lip }\end{array}$ & $\mathrm{p}$ & Significance \\
\hline $6.89+/-3.26$ & $8.49+/-1.39$ & 0.04825 & $\mathrm{~S}$ \\
\hline $\begin{array}{c}\text { Initial distance } \\
\text { aesthetic line }- \\
\text { lower lip }\end{array}$ & $\begin{array}{c}\text { Final distance } \\
\text { aesthetic line } \\
- \text { lower lip }\end{array}$ & & \\
\hline $6.52+/-2.89$ & $6.22+/-1.26$ & 0.6663 & $\mathrm{NS}$ \\
\hline
\end{tabular}

Tab. 2. The results of the statistical analysis between the positioning of the lips at the beginning and the end of the treatment for Angle class II, 12-16 age groups

In Fig. 2 and 3 are presented a graphical variation of the values obtained before and after the orthodontic treatment for the position of the upper lip to the esthetic line of Ricketts and for the position of lower lip.

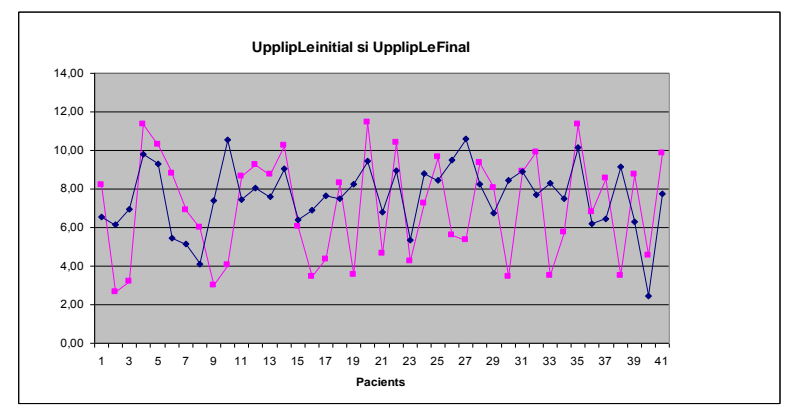

Fig. 2. Graphic representation of the variation of the initial upper lip position and final upper lip position after orthodontic treatment

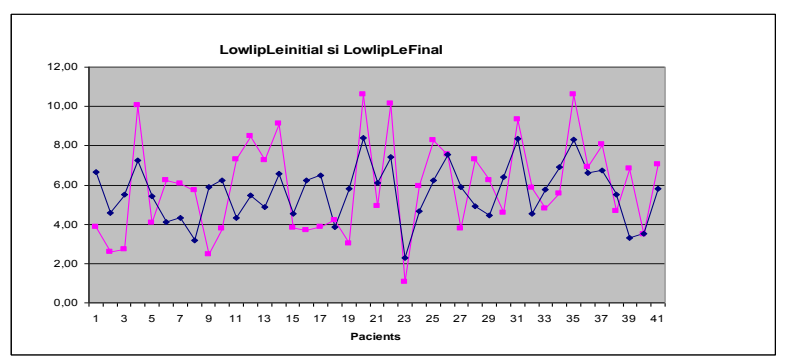

Fig. 3. Graphic representation of the variation of the initial lower lip position and final lower lip position after orthodontic treatment

\section{CONCLUSIONS}

The study will continue by measuring the influence of age and sex on facial esthetics following orthodontic treatment because this could be an important factor in establishing orthodontic treatment plan.

Orthodontists mostly evaluate soft tissue profile by means of silhouettes or, as included in this paper, linear and angular measurements made from lateral cephalometric radiographs(Ackerman M.B, 2004). However, there is no specific method for measuring esthetics(Kiekens et al., 2008).

Measurements and clinical observations of soft tissues require careful attention because of individual variations.

In this study, upper and lower lips as measured to the E line moved slightly back after treatment.
This study shows significant improvements only for class II division 1 and class II division 2, but not for class I and III.

This means that orthodontists and other clinicians should be cautious with the promises of esthetic improvement that they make to the patients and parents of patients, so that they won't be disappointed that the facial aspect is modified only to a certain degree.

\section{REFERENCES}

Ackerman M B (2004) Orthodontics and its discontents . Orthodontics andCraniofacial Research $7: 187-188$

Bergman R.T.(1999), Cephalometric soft tissue facial analysis, Am J Orthod Dentofacial Orthop ;116:373-89

Birkeland K, Katle A, Løvgreen S, Bøe O E, Wisth P J (1999) Factors influencing the decision about orthodontic treatment. Journal of Orofacial Orthopedics $60: 292-307$

Bishara SE, Jakobsen JR, Hession TJ, Treder JE. (1998) Soft tissue profile changes from 5 to 45 years of age, Am J Orthod Dentofacial Orthop. Dec; 114(6):698-706

Bravo L.A. (1994) Soft tissue profile changes after orthodontic treatment with four premolars extracted, The Angle Orthodontist, 64(1), 31-42

Bowman SJ, Johnston LE. (2000) The esthetic impact of extraction and non-extraction treatment on Caucasian patients. Angle Orthod 70:3-10

Cummins DM, Bishara SE, Jakobsen JR.(1995) A computer assisted photogrammetric analysis of soft tissue changes after orthodontic treatment. Part II: Results. Am J Orthod Dentofac Orthop 108:38-47

DiBiase AT, Sandler PJ. (2001)Does orthodontics damage faces?DentUpdate28:98-104

Goldstein, R.E. (1998) Esthetics in Dentistry 2nd Edn. Vol-1. Decker,Toronto

Kerr W J S , O’Donnell J M (1990) Panel perception of facial attractiveness .British Journal of Orthodontics $17: 299$ 304

Kiekens R., Maltha C.,Van't Hof M.A., Straatman Huub, Kuijpers-Jagtman A. (2008) Panel perception of change in facial aesthetics following orthodontic treatment in adolescents E.J. Orthod,;30(2) 141-146

Kocadereli I. (2002) Changes in soft tissue profile after orthodontic treatment with and without extractions. Am J Orthod Dentofac Orthop 122: 67-72

Morris W. (1994)An orthodontic view of dentofacial esthetics. Compend Contin Educ Dent. ;15(3):378-90

McComb J L , Wright J L, Fox N A, O’Brien K D (1996) Perceptions of the risks and benefits of orthodontic treatment . Community Dental Health $13: 133-138$

Peck S, Peck H. (1971) The aesthetically pleasing face: An orthodontic myth. Trans Eur Orthod Soc ; 47: 175-185

Szuhanek, C., Cernescu A., Faur N., Fleser T., Vatau S., Cheveresan A.(2009) Numerical simulation of orthodontic forces effects in bone loss cases Proceedings of the 20th International DAAAM Symposium "Intelligent Manufacturing \& Automation: Focus on Theory, Practice and Education, 25-28th November, ISBN 978-3-90150970-4, ISSN 1726-9679, Published by DAAAM International, Vienna, Austria 2009, pp. 953-954

Szuhanek C.A., A. Cernescu, N. Faur, F. Glavan, T. Fleser, S. Vatau,(2009) "Finite Element Simulation of First Molar Movement During Orthodontic Treatment", ISI Proceedings of the 20th International DAAAM Symposium "Intelligent Manufacturing \& Automation: Focus on Theory, Practice and Education, 25-28th November , ISBN 978-3-901509-70-4, ISSN 1726-9679, Published by DAAAM International, Vienna, Austria 2009, pp. 953-954

Zachrisson BU.(1998) Esthetic factors involved in anterior tooth display and smile: vertical dimension. J Clin Orthod. ;32(7):432-45 